\title{
Acid Test of Ghana's Educational Institutions Operating Distance Learning Programs
}

\begin{abstract}
The outbreak of the COVID-19 pandemic is an unprecedented blow to the Ghanaian Educational System. Following the closure of all educational facilities in Ghana in March 2020, the country's President ordered for the adoption of distance learning. This poses the question: how prepared are Ghanaian institutions to carry out distance learning using online teaching approaches? Most institutions in Ghana offering distance learning programs currently adopt the usage of the tutorial method where there is minimal or no usage of online learning technologies. This article discusses the potential usage of mobile learning by Ghanaian Educational Institutions operating distance learning programs in the wake of combating the COVID-19. It proposes a model to support the use of WhatsApp Messenger as an online tool to support distance learning programs. The proposed model is a summary comparison between a typical Learning Management System (LMS) using Jurado's classification and the proper application of the use of WhatsApp Messenger as a mobile learning platform in a Ghanaian context.
\end{abstract}

\section{WILLIAM K. KOOMSON \& NAA KAI AMANOR-MFOAFO ${ }^{1}$}

${ }^{1}$ William K.Koomson, PhD is an Associate Professor of Education Valley View University Oyibi Ghana.

Email:william.koomson@vvu.edu.gh Naa Kai Amanor-Mfoafo holds an MSc in Information Technology from the University of Aberdeen, UK and MBA(Management Information Systems) from KNUST-Ghana. Email:naakaiam@noyam.org

\section{Manuscript}

Received 5th May 2020,

Accepted 22nd May 2020,

Published online 27th May 2020.

Keywords: Corona Virus (COVID-19), Distance learning, m-Learning, Whatsapp messenger.

\section{INTRODUTION}

Coronavirus, also called COVID-19, is real and has the best brains in the world thinking about quick-fix solutions, but none seem to be apparent. COVID-19 has been described as an infectious disease caused by the newly discovered coronavirus with most infected people experiencing mild to moderate respiratory illness. ${ }^{2}$ COVID-19 was first identified in December 2019 in Wuhan, the capital of China's Hubei province, and has since spread globally, resulting in the ongoing 2019-20 coronavirus pandemic. ${ }^{3}$ As it stands now, no one understands the disease, and any possible vaccine to cure the virus is months away, while precious souls continue to perish. The nations' leaders have gone out of their way to reduce panic and fear as they try all possible means to lessen the grip of this killer-disease.

Most governments around the world have temporarily closed educational institutions in an attempt to contain the spread of the COVID-19 pandemic. ${ }^{4}$ Across Italy, as Mark Lowen put it, "the perennial problem has struck early this year: with schools and universities now closed (across the nation), in an effort to contain the spread of coronavirus, some 8.4 million children are out of class well before the Easter break. ${ }^{5}$ It's an unprecedented response by Europe's worst-hit country." This sentiment cut across all countries in the World. In the USA, UK, Canada, Australia, Germany,

\footnotetext{
"Coronavirus," World Health Organization, accessed April 10,2020, https://www.who.int/health-topics/coronavirus\#tab=tab_1.

David S. Hui, Esam Azhar and Tariq A.Madani, "The continuing 2019-nCoV epidemic threat of novel coronaviruses to global health - The latest 2019 novel coronavirus outbreak in Wuhan, China." International Journal of Infectious Diseases, 91(2020): 264-6.

4 “COVID-19 Educational Disruption and Response," UNESCO, accessed April 11, 2020 - https://en.unesco.org/covid19/educationresponse Mark Lowen, "Coronavirus: Italy to close all schools as deaths rise.” BBC News, accessed March 20, 2020 https://www.bbc.com/news/ world-europe-51743697
} 
and many other countries; daily presidential press briefings aiming to provide possible solutions have been the norm. Schools are closed, mass gatherings canceled, national transportation systems grounded, and workers that provide fuel to the economy have been asked to lay down their tools and go home. These drastic measures have been undertaken by world leaders to help contain the spread of the disease. These closures and mandatory stay-at-home measures have consequences. Unlike the 2008 financial crisis that grounded many less-developed economies, many countries either developed or less developed, including Ghana are vulnerable.

NEVERTHELESS, THERE IS HOPE. COVID-19 will eventually be conquered and finally eliminated, even though there is currently no information on know how long the pandemic would last. Instead of trading pani c, alarm and doomsday prophecies, there is the need to be calm, prayerful, positive and observe all personal safety measures whilst seeking special protection from our Lord. In this time of distress, there is the need to rely on the many promises found in the Abrahamic text, including this one:

the LORD appeared to him (Solomon) at night and said: "I have heard your prayer and have chosen this place for myself as a temple for sacrifices. "When I shut up the heavens so that there is no rain, or command locusts to devour the land or send a plague among my people, if my people, who are called by my name, will humble themselves and pray and seek my face and turn from their wicked ways, then I will hear from heaven, and I will forgive their sin and will heal their land. Now my eyes will be open and my ears attentive to the prayers offered in this place (2 Chronicles 7:12-15).

\section{Acid Test of Ghana's Educational Institutions: Are They Prepared?}

Leaders from many nations that have been hit with the disease have decidedly cancelled schools and mass gatherings. The President of Ghana - Nana Addo Danquah Akuffo-Addo on the $18^{\text {th }}$ of March 2020 ordered the closure of all public and private schools and halted all forms of public gatherings in the country as part of measures to prevent a possible outbreak of the coronavirus in the country". ${ }^{6}$ He further ordered the Ministry of Education in collaboration with the Ministry of Communication to roll out distance learning programs. ${ }^{7}$ This, in the authors view, is realistic and achievable but in the face of the country's current educational structures regarding distance learning, can be considered a tall order.

Are the educational institutions, both pre-tertiary and tertiary, ready for distance learning programs? Which distance learning model should they adopt, and what can they expect from it? By distance, the President may have been referring to learning aided by technology where learners and instructors are separated by space with teaching and learning done asynchronously. Many developed nations can be considered to be ready to swiftly move online because they previously were partially doing so. Schools in Ghana have not yet achieved the online parity, and though it is possible, the educational policy makers have to invest in developing online learning infrastructure that do not rely heavily on tutorial center operations as is the case in most tertiary institutions that operate distance learning programs in Ghana. With this background this article seeks to explore online learning using mobile technology. It further proposes a model to support the use of Whatsapp Messenger as mobile learning (m-Learning) tool for distance learning programs.

\section{Providing Context Specific Distance Learning Programs}

Distance learning models have gone through various generations. According to Heydenrych and Prinsloo the world is currently in Generation 5. ${ }^{8}$ The earlier generations relied heavily on newly developed technologies such as the printing press, books, film, animation, radio and television, shorthand (i.e., Gregg Shorthand), Video Home System (VHS), computer assisted learning, floppy diskette, telephones, telegrams and faxes, telex and teleprinters, video conferencing, audio-graphics, pen or flash drives, internet and the World-Wide-Web, and Web 2 to Web 4 technologies. ${ }^{9}$ The technology powered distance learning programs, moved from the Correspondence School system to the direct learning systems and to the latest eLearning/mLearning systems. Therefore, the use of the word technology in distance learning does not solely denote online learning or learning powered by the latest learning management systems (LMS). Many equate distance learning to online learning and that any distance learning programs without the use of the LMS are not truly online. $^{10}$

Technology, therefore, is a conduit through which distance learning programs are powered. The technology is not the end of itself; its primary purpose is to deliver the curriculum to the learners. Newly developed technologies have

\footnotetext{
6 “Timeline: Ghana's fight against Covid-19 exactly a month after recording first cases", My Joy Online, accessed April 10, 2020 https:// www.myjoyonline.com/news/national/timeline-ghanas-fight-against-covid-19-exactly-a-month-after-recording-first-cases/

My Joy Online, “Timeline: Ghana's fight against Covid-19 exactly a month after recording first cases”.

8 Japie Heydenrych and Paul Prinsloo, "Revisiting the five generations of distance education: Quo vadis?, Progressio," South African Journal for Open and Distance Learning Practice, 32 no.1(2010): 5-26.

Japie and Paul, "Revisiting the five generations of distance education: Quo vadis?, Progressio," 5-26.

10 Japie and Paul, "Revisiting the five generations of distance education: Quo vadis?, Progressio," 5-26.
} 
offered increased opportunities for the educational industry, however, they are not the savior or the message, they are the messenger in the context of less developed countries. Considering the earlier examples given of distance learning technologies, one may infer that a floppy diskette or a teleprinter was once an enviable technology.

Heydenrych \& Prinsloo ${ }^{11}$ have proposed the following seven standards to address future generation of distance learning to be context-specific:

1. Students form part of peer collaborative groups and communities of practice, which they share with alumni, employers, community members and tutors.

2. Institutions will have to design appropriate blended learning options in a menu of service from which students can tailor-make their learning experiences, to allow for maximum self-organisation of learning with support.

3. Higher education institutions have, for too long, distanced themselves from the communities in which they themselves are located, and from which their students originate. Higher education will have to find creative ways to speak 'from place' and 'to place', from their specific location within the broader network (consisting of communities, employers, families and other stakeholders).

4. Giving students access to wireless and remote technologies through negotiation with providers.

5. Learning is no longer content driven, but shaped and paced by activities- and inquiry-based learning, which is embedded in the current and future student, and in employment and societal contexts.

6. Regional production facilitates the speedy distribution of learning materials;

7. Making use of (and contributing to) generic and open content, which can be accessed from multiple platforms (all forms of smart devices).

\section{Mobile Phone Diffusion in Teaching and Learning}

Mobile technologies with cellular connectivity continue to dominate the information communication technology market in sub-Saharan Africa. According to the Pew Research Center, cell phone usage in Africa pales in comparison to that of developed countries like the United States of America. ${ }^{12}$ However, there has been a dramatic surge in the growth of smartphone usage in sub-Saharan Africa. As of 2014, the following countries recorded high percentages of cell phone usage; Uganda 65\%, Tanzania 73\%, Kenya $82 \%$, Ghana $83 \%$, and South Africa, $89 \%$. In the same year, the United States' cell phone usage was $89 \%$, the same as in South Africa and only in single-digits, higher than Ghana and Kenya. Among the many uses of cell phones in Africa for a twelve-month period, texting was at the forefront. ${ }^{13}$

Myjoyonline reported that Ghana was ranked by the International Telecoms Union Report as number one in Africa with more people using or connected to mobile broadband. ${ }^{14}$ Laary stated that for the period ending December 2015 , Ghana's mobile phone voice penetration rate surged to $128 \%$, far above earlier projections by telecommunication experts. ${ }^{15}$ The adoption of mobile technology with its diverse apps can serve as a conduit for mobile learning.

In Ghana, the most common format adopted in Distance Learning is the tutorial format, where very few online interactions occur; in most instances, there are no online interactions. The universities that enroll their students through the distance learning mode, rely heavily on print materials in the form of course modules and students meet regularly during weekends in tutorial centers throughout the nation where they receive face-to-face instructions. Very few programs include videos and voice presentations in their distance learning pedagogy. ${ }^{16}$

However, with mobile learning technologies like "WhatsApp Messenger," developing countries have no excuses as to why they are not able to adopt online learning in the remotest parts of the country where connectivity is a major setback. Everywhere a mobile phone is used, whether for WhatsApp, Email, SMS, video or photo sharing, online learning may be possible. In the academic environments, just as in the community, households and business places, WhatsApp Messenger has been used to create group chats for work teams, social networking, and learning.

\section{WhatsApp Messenger for m-Learning}

Research on the application of WhatsApp Messenger in the classroom is new and developing, however, its usage as a

11 Ibid.

12 "Cell Phones in Africa: Communication Lifeline" Pew Research Center Surveys. Spring 2014 global attitudes survey: Q68(2015). Accessed 2019 www.pewglobal.org/2015/04/15/cell-phones-in-africa-communication-lifeline/

13 Pew Research Center Surveys , "Cell Phones in Africa: Communication Lifeline".

14 "Increase use of smartphones made Ghana No-1in mobile broadband penetration.” My Joy Online, (2013). http://myjoyonline.com/pages/news/201301/99976.php

15 Dasmani Laary, "Ghana: Mobile phone penetration soars to 128\%.” The Africa Report (2016), accessed 2019 https://www.theafricareport.com/1800/ghana-mobile-phone-penetration-soars-to-128/

16 Alberta Tackie, Evans Ankomah-Asare and Nicholas Nsowah-Nuamah, "Distance education in Ghana: An overview of enrolment and programme patterns", Distance education in Ghana: An overview of enrolment and programme patterns. Proceedings of INCEDI 2016 Conference, (Accra, Ghana:2016) $184-190$. 
social media tool on smartphones is widespread. ${ }^{17}$ WhatsApp is the most popular mobile messaging application widely used worldwide and it is ranked as the number one in terms of monthly active users, based on a study of over 22,500 sources worldwide. ${ }^{18}$ WhatsApp, however, announced that, the messaging app is now being actively used by more than 2 billion people worldwide. ${ }^{19}$

WhatsApp features include:

- Text - simple and reliable;

- Group Chat - keeping in touch with love ones, people in your network, business partners, and parishioners;

- On the Web and Desktop - keeping the conversation going anytime, anyplace, anywhere;

- Voice and Video Calls - free face-to-face conversation, when voice and text are not enough;

- End-to-End Encryption - provides security by default;

- Photos and Videos - opportunity to share moments that matter;

- Voice Messaging - using the voice messaging system to convey emotional moments;

- Documents - attaching and sharing documents including PDFs, spreadsheets, slideshows, photos, and Word documents. ${ }^{20}$

WhatsApp Messenger features make it easy for teaching and learning. The app uses phone internet connections (4G/3G/2G/EDGE of Wi-Fi) of users to send and receive messages. That is, as long as there is data on users' phones, sending and receiving messages are free. ${ }^{21}$ WhatsApp announced in May 2018 at its F8 developer conference in San Jose, California, that over 65 billion messages have been sent by users with more than 2 billion minutes of voice and video calls made every day on the app platform, and about 1 billion people use this messaging app each day. ${ }^{22}$

\section{Promoting Learner Interaction in Distance Learning}

Jurado, et al, classified learning management systems features into four different tool groups, namely: distribution, communication, interaction, and administration. ${ }^{23}$

1. Tools for distribution allow lecturers to upload documents, available to students. Earlier it was mainly text documents and today it may also be different kinds of media files. Nevertheless, the process is still one-way, that is, teacher-to-learner distribution of information.

2. Tools for communication allow information to go either way as well as from student-to-student. The most common example is E-mail.

3. Tools for interaction call for reaction and feedback. Discussion boards are the most typical example. These tools are of great interest since they may promote student activity and cooperation, hence enhancing the learning experience.

4. Tools for course administration are used to monitor and document the educational process, rather than to facilitate teaching or learning (p.4).

Jurado's classification focus on course administration; teacher-to-student and student-to-student interactions. Any form of distance learning program that lacks the interactivity piece is not complete and is missing the core pedagogical attributes of teaching and learning. That is, clarity and focus of learning objectives, selection of media and integration of the media selected to address learning goals. Fourth and fifth generation distance learning programs promote synchronous and asynchronous interactions through discussion forums; teacher-student; student-teacher; studentstudent (peer) interactions. Any form of distance program that does not meet the above criteria cannot be properly characterized as Distance Learning. These types of programs must be properly labeled as adult extension programs or adult weekend programs.

17 Cetinkaya, 2017; Bouhnik \& Deshen, 2014; Yeboah \& Ewur, 2014; Church \& de-Oliviera, 2013

18 "Most popular mobile messaging apps worldwide as of April 2018, based on number of monthly active users (in millions)." Statista, (2018), accessed $2019 \mathrm{https} / /$ www.statista.com/statistics/258749/most-popular-global-mobile-messenger-apps/

19 Birgit Bucher, "WhatsApp, WeChat and Facebook messenger Apps - Global messenger usage, penetration and statistics." 2020 accessed April 10,2020 https://www.messengerpeople.com/global-messenger-usage-statistics/

20 "WhatsApp Features" accessed April 10,2020 http://www.whatsapp.com/features/

${ }_{21}$ "Is it free to send messages over WhatsApp?” accessed April 10,2020 https://faq.whatsapp.com/en/android/20965922/.

22 Abrar Al-Heeti, "WhatsApp: 65B messages sent each day, and more than 2B minutes of calls"(2018) accessed July 14, 2018 https://www.cnet.com/news/whatsapp-65-billion-messages-sent-each-day-and-more-than-2-billion-minutes-of-calls/

${ }^{23}$ Jurado, R. G., Pattersson, T., Regueiro-Gomez, A. \& Scheja, M., "Classification of the feature in learning management systems." XVII Scientific Convention on Engineering and Architecture, Havana City, Cuba (2014). 


\section{METHODOLOGY}

\section{Media Selection}

WhatsApp Messenger as a social media tool is inherently interactive for social media purposes. This important feature has been explored by many researchers to augment teaching and learning in developing countries. ${ }^{24}$ According to Tony Bates, ${ }^{25}$ timely and appropriate feedback from the instructor to the learner is an important aspect of interaction. Thus, when it comes to media selection, the following questions are worth considering:

1. To what extent is interaction enabled or controlled by the media selected?

2. To what extent is feedback possible within a particular medium?

3. What kind of interaction will best lead to a particular type of learning outcome, and what technology or medium best provides this kind of interaction?

Tony Bates' SECTIONS model has been used by many researchers in the Distance Education industry. ${ }^{26}$ Bates' framework provides a set of criteria to help inform educational institutions or educational providers when making decisions regarding the choice of appropriate media for teaching and learning. SECTIONS model stands for Students, Ease of Use, Cost, Teaching functions, Interaction, Organizational issues, Networking, and Security and privacy issues. Regarding media selection, Walter McKenzie ${ }^{27}$ posited that:

People are not always conscious of each medium they encounter; mode of delivery seems to get lost in the mix as we are inundated by volumes of information in endless cycles. While it is easy to become desensitized as consumers of information, as educators we are in a unique position to maximize media selection and get a handle on this explosion of information for our students. As McLuhan suggested prophetically, the medium may not only be the messenger, it may be the message.

When I am discussing the current state of technology with teachers around the country, it becomes clear that they feel bound by their access to technology, regardless of their situation. If a teacher has a television-computer setup, then that is what he or she will use in the classroom. On the other hand, if there is an LCD projector hooked up to a teacher demonstration station in a fully equipped lab, he or she will be more apt to use that set up. Teachers have always made the best of whatever they've got at hand, but it's what we have to work with. Teachers make due.

The author presents in table 1, a mobile learning structure indicating a summary comparison between a typical Learning Management System (LMS) using Jurado's classification and the proper application of the use of WhatsApp as mobile learning platform in a Ghanaian context.

\footnotetext{
24 Bouhnik \& Deshen, 2014; Cetinkaya, 2017; Church \& de Oliveira, 2013; Gronlund \& Islam, 2010; Koomson, 2019; Motlik, 2008

25 Tony Bates, "Teaching in a digital age: Guidelines for designing teaching and learning." Tony Bates Associates Ltd. (Vancouver BC: 2015), accessed 2019 https://opentextbc.ca/teachinginadigitalage/

26 Tony Bates,"Teaching in a digital age: Guidelines for designing teaching and learning".

27 Walter McKenzie, Multiple Intelligences and Instructional Technology: A Manual for Every Mind (International Society for Technology in Education, 2002), 6
} 
Table 1. Proposed Model: Mobile Learning Structure Using WhatsApp Messenger - Ghanaian Context (Remote Access $)^{28}$

\begin{tabular}{|c|c|c|c|c|}
\hline $\begin{array}{l}\text { Application: } \\
\text { Online learning } \\
\text { tools. Jurado, } \\
\text { et al }{ }^{29}\end{array}$ & $\begin{array}{l}\text { Key Players: } \\
\text { Students/faculty/ } \\
\text { support staff/ } \\
\text { administrators }\end{array}$ & $\begin{array}{l}\text { Purpose: } \\
\text { Teaching and } \\
\text { learning using } \\
\text { blended mode of } \\
\text { online learning }\end{array}$ & $\begin{array}{l}\text { Learning Management } \\
\text { System (LMS): } \\
\text { Why LMS may not work in } \\
\text { some areas in Ghana due to } \\
\text { lack of Internet Access }\end{array}$ & $\begin{array}{l}\text { WhatsApp for learning: } \\
\text { How WhatsApp may work in } \\
\text { many areas in Ghana despite } \\
\text { lack of Internet Access. } \\
\text { Students who possess smart } \\
\text { phones only need data. }\end{array}$ \\
\hline Distribution & $\begin{array}{l}\text { 1. Faculty } \\
\text { 2. Student } \\
\text { Interaction flows } \\
\text { from teacher to } \\
\text { student }\end{array}$ & $\begin{array}{l}\text { One-way: from } \\
\text { teacher to student - } \\
\text { one way process }\end{array}$ & $\begin{array}{l}\text { 1. Teacher sends course } \\
\text { information to } \\
\text { students via the course } \\
\text { management systems } \\
\text { 2. Students retrieve course } \\
\text { information } \\
\text { 3. LMS delivers courseware } \\
\text { over the internet } \\
\text { 4. Students lack access to } \\
\text { retrieve and view course } \\
\text { content via the internet. }\end{array}$ & \begin{tabular}{|l} 
1. \\
Teacher sends course \\
information via PDFs \\
or Word document \\
attachments to students \\
2. Students sign their name \\
(forum signature) before \\
each WhatsApp post \\
3. Students retrieve course \\
information \\
4. WhatsApp Messenger uses \\
phone internet connections \\
5. As long as there is data on \\
students' phones, viewing \\
course content is possible.
\end{tabular} \\
\hline Communication & $\begin{array}{l}\text { 1. Faculty } \\
\text { 2. Student } \\
\text { Interaction flows } \\
\text { both ways }\end{array}$ & $\begin{array}{l}\text { Information } \\
\text { goes either way. } \\
\text { Teacher to student, } \\
\text { student to teacher }\end{array}$ & $\begin{array}{l}\text { 1. Students respond to } \\
\text { teacher via the course } \\
\text { management system } \\
\text { 2. Teacher grades students } \\
\text { work and post comments } \\
\text { on course management } \\
\text { system } \\
\text { 3. Students lack access to } \\
\text { retrieve and view course } \\
\text { content via the internet. }\end{array}$ & $\begin{array}{l}\text { 1. Students post completed } \\
\text { assignments in more than } \\
\text { one format via: } \\
\text { a. PDF or Word } \\
\text { attachments } \\
\text { b. Direct text message } \\
\text { 2. Teacher grades students } \\
\text { work and post comments } \\
\text { via WhatsApp Messenger } \\
\text { 3. Teacher sends transcripts of } \\
\text { WhatsApp communication } \\
\text { to course administrators } \\
\text { at the end of the class for } \\
\text { archival purposes. }\end{array}$ \\
\hline Interaction & $\begin{array}{l}\text { 1. Faculty } \\
\text { 2. Students } \\
\text { Peer interactions. } \\
\text { Student to student }\end{array}$ & $\begin{array}{l}\text { Discussion boards, } \\
\text { students reactions } \\
\text { and feedbacks. }\end{array}$ & $\begin{array}{l}\text { 1. Student to student } \\
\text { interaction through LMS } \\
\text { discussion forums } \\
\text { 2. Teacher as facilitator } \\
\text { guides students }\end{array}$ & $\begin{array}{l}\text { 1. Students to student } \\
\text { interaction through: } \\
\text { a. WhatsApp 'group-chat' } \\
\text { b. Possible video and voice } \\
\quad \text { calls } \\
\text { 2. Teacher as facilitator guides } \\
\text { students }\end{array}$ \\
\hline
\end{tabular}

\footnotetext{
${ }_{28}$ William Koomson, "Ontology of ubiquitous learning: WhatsApp Messenger competes successfully with learning management systems (LMS) in Ghana. ”(2019). International Conference Educational Technologies 2019 https://eric.ed.gov/?id=ED601178

29 Jurado, R. G., Pattersson, T., Regueiro-Gomez, A. \& Scheja, M., "Classification of the feature in learning management systems."
} 


\begin{tabular}{|c|c|c|c|c|}
\hline $\begin{array}{l}\text { Course } \\
\text { Administration }\end{array}$ & $\begin{array}{l}\text { 1. Support Staff } \\
\text { 2. Administrators } \\
\text { Back-end } \\
\text { interaction }\end{array}$ & $\begin{array}{l}\text { Course monitoring, } \\
\text { management, } \\
\text { documentation, and } \\
\text { evaluation. }\end{array}$ & $\begin{array}{l}\text { 1. Teacher/support staff } \\
\text { setup the courses via the } \\
\text { LMS } \\
\text { 2. Teacher post course } \\
\text { syllabus and assignments } \\
\text { for class discussions } \\
\text { 3. Teacher grades students } \\
\text { work and post grades } \\
\text { online } \\
\text { 4. Students perform teacher } \\
\text { and course evaluations } \\
\text { online }\end{array}$ & $\begin{array}{l}\text { 1. Support staffs create } \\
\text { WhatsApp groups for } \\
\text { students and faculty } \\
\text { 2. Support staff monitors } \\
\text { students and faculty } \\
\text { interactions through } \\
\text { WhatsApp transcripts } \\
\text { 3. Support staff receives } \\
\text { transcripts from teachers } \\
\text { regularly and monitors } \\
\text { for course content and } \\
\text { interactions } \\
\text { 4. Teacher sends WhatsApp } \\
\text { transcripts to program office } \\
\text { for archival purposes. } \\
\text { 5. Support staff archives } \\
\text { course materials for quality } \\
\text { control purposes. }\end{array}$ \\
\hline
\end{tabular}

\section{CONCLUSION}

In the above analysis, the authors are of the opinion, based on best practices, that for WhatsApp to work properly in any classroom in Ghana, there must be intentional designs and a step-by-step approach to teach both the teachers and the students how to use the application to achieve the best outcomes. When it comes to choosing a medium for distance learning program in Ghana, there is no one-size-fit-all approach. In many instances, "a medium will require the intervention of a teacher or instructor both to set activities around the learning materials and to provide appropriate feedback, thus adding to rather than reducing the workload of instructors." Also "where instructors have to intervene either to design activities or to provide feedback, the cost or time demands on the instructor are likely to be greater" ${ }^{30}$

The author also believes that, teaching both teachers and students how to use WhatsApp for educational purposes in distance learning environment is possible, because "seemingly intractable problems have been solved by advances in processing power and capabilities. Not long ago, autonomous vehicles were considered technologically infeasible due to the volume of data that needed to be processed in real time. Speech recognition was unreliable and required extensive speaker-dependent training sessions. Mobile phones were once "auto-mobile" phones, requiring a car trunk full of equipment". ${ }^{31}$

Properly integrated, mobile learning powered by WhatsApp Messenger may be the solution for our country and many other developing nations. National emergencies like the COVID-19 and others yet to come are indicators to alert us for proper planning and implementation of a robust distance learning programs across the country. We must leave no stone unturned in this venture, as we together seek out the best utilization of ubiquitous technologies for teaching and learning.

\section{BIBLIOGRAPHY}

Al-Heeti, Abrar,"WhatsApp: 65B messages sent each day, and more than 2B minutes of calls."

C/net News. 2018 Accessed July 14, 2018.https://www.cnet.com/news/whatsapp-65-billion-messages-senteach-day-and-more-than-2-billion-minutes-of-calls/

Bates, Tony, Teaching in a digital age: Guidelines for designing teaching and learning.

Vancouver BC: Tony Bates Associates Ltd, 2015 ISBN: 978-0-9952692-0-0.

https://opentextbc.ca/teachinginadigitalage/

Bouhnik, D. and Deshen, M, WhatsApp goes to school: Mobile instant messaging between teachers and students. Journal of Information Technology Education: Research, 13. (2014): 217-231.

\footnotetext{
30 Tony Bates,"Teaching in a digital age: Guidelines for designing teaching and learning".303

31 Earley, S, “There's no AI (artificial intelligence) without IA (information architecture).” IT Professionals 18 no.3(2017):58-64. Doi: 10.1109/MITP.2016.43
} 
Bucher, Birgit, "WhatsApp, WeChat and Facebook messenger Apps - Global messenger usage, penetration and statistics." 2020. Accessed: https://www.messengerpeople.com/globalmessenger-usage-statistics/

Cetinkaya, L, "The impact of WhatsApp use on success in education process." The International Review of Research in Open and Distributed Learning. 18 no.7 (2017) doi: 10.19173/irrodl.v18i7.3279.

Church, K. and de Oliveira, R, "What's up with WhatsApp? Comparing mobile instant messaging behaviors with traditional SMS." In Proceedings of the 15th International Conference on HumanComputer Interaction with Mobile Devices and Services (MobileHCI),Munich, Germany (2013) :352-361.

"Coronavirus," World Health Organization.(2020) Accessed April 10,2020, https://www.who.int/health-topics/coronavirus\#tab=tab_1.

Earley, S, “There's no AI (artificial intelligence) without IA (information architecture)." IT Professionals 18 no.3(2017): 58-64. Doi: 10.1109/MITP.2016.43

Gronlund, A., and Islam, Y, “A mobile e-learning environment for developing countries: The Bangladesh virtual interactive classroom." Information Technology for Development, 16, no.

4. (2010): 244-259. doi:10.1080/02681101003746490

Heydenrych, Japie and Prinsloo, Paul., "Revisiting the five generations of distance education: Quo vadis?, Progressio," South African Journal for Open and Distance Learning Practice, 32, no. 1 (2010): 5-26.

Hui, D. S., Azhar, E. I., and Madani, T. A., "The continuing 2019-nCoV epidemic threat of novel coronaviruses to global health - The latest 2019 novel coronavirus outbreak in Wuhan, China." International Journal of Infectious Diseases, 91, (2020).

Jurado, R. G., Pattersson, T., Regueiro-Gomez, A. \& Scheja, M., "Classification of the feature in learning management systems." XVII Scientific Convention on Engineering and Architecture, Havana City, Cuba (2014).

Koomson, William. K. "Ontology of ubiquitous learning: WhatsApp Messenger competes successfully with learning management systems (LMS) in Ghana" International Conference Educational Technologies 2019 (2019). Accessed 2020 https://eric.ed.gov/?id=ED601178

Laary, Dasmani, "Ghana: Mobile phone penetration soars to $128 \%$.” The Africa Report. (2016) Accessed 2019 www.theafricareport.com/West-Africa/ghana-mobile-phone-penetration-soars-to-128.html

Lowen, Mark, "Coronavirus: Italy to close all schools as deaths rise." BBC News. (2020). Accessed 2020 https://www.bbc.com/news/world-europe-51743697

Motlik, S, "Mobile learning in developing nations. Technical Evaluation Report." The International Review of Research in Open and Distance Learning, 63, No. 9. (2008) : 2.

MyJoyOnline, "Timeline: Ghana's fight against Covid-19 exactly a month after recording first cases." (2020). Accessed April 10,2020

https://coronavirus.com.gh/timeline-ghanas-fight-against-covid-19-exactly-a-month-after-recording-firstcases/

MyJoyOnline, "Increase use of smartphones made Ghana No-1in mobile broadband penetration." (2013) Accessed https:business.myjoyonline.com/pages/news/201301/99976.php

Pew Research Center Surveys, "Cell Phones in Africa: Communication Lifeline" Spring 2014 global Attitudes survey." (2015): Q68 Accessed www.pewglobal.org/2015/04/15/cell-phones-in-africa-communication-lifeline/

Statista, "Most popular mobile messaging apps worldwide as of April 2018, based on number of monthly active users (in millions)." The Statistics Portal. Accessed https://www.statista.com/ statistics/258749/most-popular-global-mobile-messenger-apps/

Tackie, Alberta, L., Ankomah-Asare, Evans and Nsowah-Nuamah, Nicholas, "Distance education in Ghana: An overview of enrolment and programme patterns. " Proceedings of INCEDI 2016 Conference, Accra, Ghana (2016):184 - 190.

McKenzie, Walter, Multiple Intelligences and Instructional Technology: A Manual for Every Mind. International Society for Technology in Education, 2002.

WhatsApp FAQ's, “Is it free to send messages over WhatsApp?"(2020). Accessed April 10,2020 https://faq.whatsapp.com/en/android/20965922/.

WhatsApp Features, (2020). Accessed April 10,2020 http://www.whatsapp.com/features/

Yeboah, J. and Ewur, G. D, “The impact of WhatsApp Messenger usage on students' performance in tertiary institutions in Ghana." Journal of Education and Practice. 5 no 14.(2014):157-164. 